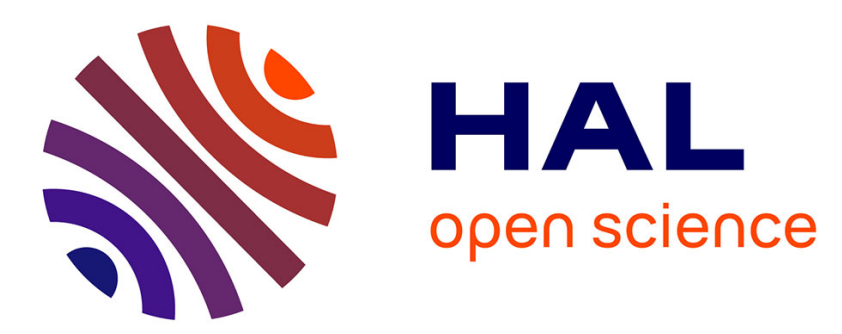

\title{
The interaction between Aegean back-arc extension and Anatolia escape since Middle Miocene
}

Melody Philippon, Jean-Pierre Brun, Frédéric Gueydan, Dimitrios Sokoutis

\section{To cite this version:}

Melody Philippon, Jean-Pierre Brun, Frédéric Gueydan, Dimitrios Sokoutis. The interaction between Aegean back-arc extension and Anatolia escape since Middle Miocene. Tectonophysics, 2014, 631, pp.176-188. 10.1016/j.tecto.2014.04.039 . insu-01066042

\section{HAL Id: insu-01066042 \\ https://hal-insu.archives-ouvertes.fr/insu-01066042}

Submitted on 19 Sep 2014

HAL is a multi-disciplinary open access archive for the deposit and dissemination of scientific research documents, whether they are published or not. The documents may come from teaching and research institutions in France or abroad, or from public or private research centers.
L'archive ouverte pluridisciplinaire HAL, est destinée au dépôt et à la diffusion de documents scientifiques de niveau recherche, publiés ou non, émanant des établissements d'enseignement et de recherche français ou étrangers, des laboratoires publics ou privés. 


\section{The interaction between Aegean back-arc extension and Anatolia escape since Middle Miocene}

Melody Philippon ${ }^{1}$, Jean-Pierre Brun ${ }^{2}$, Frédéric Gueydan ${ }^{1}$ and Dimitrios Sokoutis ${ }^{3,4}$

1. Geosciences Montpellier UMR 5243CNRS, Université de Montpellier 2, 34095 Montpellier Cedex 5, France.

2. Géosciences Rennes, UMR 6118, Université Rennes 1 \& CNRS, 35042 Rennes Cedex, France.

3. Utrecht University, Faculty of Earth Science, Budapestlaan 4, 3584 CD Utrecht, The Netherlands.

4. University of Oslo, Department of Geosciences, PO Box 1047 Blindern, NO-316 Oslo, Norway.

Keywords: back-arc extension, Anatolia escape, Hellenic trench retreat, reactivation of suture zone, north Anatolian fault.

\section{Abstract}

The Aegean domain is a key area for understanding the processes of back-arc extension. Observed deformation pattern and present day kinematics result from the interaction between the southward retreat of the Hellenic trench and the westward escape of Anatolia. Lithosphere-scale analogue models were employed to display that the overall pattern of Aegean extension requires not only the combination of trench retreat and Anatolia escape since middle Miocene but also the presence of an inherited 
lithosphere-scale mechanical discontinuity: the Vardar Suture Zone (VSZ). The reactivation in dextral shear of the eastern branch of the VSZ accommodates both the trench retreat (NS stretching) and the westward escape of Anatolia (EW shortening) in the Cyclades area since middle Miocene. Additionally, our model shows that the North Anatolian Fault (NAF) is a late structure in the evolution of the Aegean, initiated around $10 \mathrm{Ma}$ after the onset of Anatolia escape. The displacement field at the surface of the model allows the identification of sub-domains, which result from strain partitioning instead of being "rigid microplates", directly comparable to the present-day displacement field (GPS) of the Aegean and western Anatolia. Our model provides a simple but powerful way to look at the dynamics of Aegean extension in two main stages. From middle Eocene to middle Miocene, extension was only driven by the southward retreat of the Hellenic trench at a rate lower than $1 \mathrm{~cm}^{-y^{-1}}$. Since middle Miocene, the combination of slab rollback with Anatolia westward escape, resulted in a southwest direction of trench retreat, with an accelerating rate of up to 3 $\mathrm{cm} \cdot \mathrm{y}^{-1}$.

\section{Introduction}

Since the first plate kinematic models of eastern Mediterranean (McKenzie 1972, 1978; Dewey and Sengör, 1979; Le Pichon and Angelier, 1981), the Neogene tectonic history of the Aegean is described as the result of an interaction between back-arc extension and westward displacement of Anatolia. The North Anatolian Fault (NAF) is the transform fault along which Anatolia slips westward. Satellite geodesy (Mc Clusky et al., 2000) demonstrated that the present-day regional displacement pattern that results from this interaction (Fig. 1a), corresponds to a combination of $3.3 \mathrm{~cm} \mathrm{y}^{-1}$ southward retreat of the Hellenic trench and $2.1 \mathrm{~cm}$ 
$\mathrm{y}^{-1}$ westward displacement of Anatolia. Arguments related to seismicity, earthquake risk and spatial geodesy have contributed to focus attention on the NAF and consequently a large amount of studies has been dedicated to this particular fault and closely related structures. However, the NAF results from progressive strain localisation within the wedge-shape North Anatolian Shear Zone (NASZ) that is $100 \mathrm{~km}$ wide at its western end (Sengör et al., 2005). Dextral strike-slip shear initiated in eastern Anatolia, along the Bitlis Suture, around 11-13 Ma. The localisation of the NAF inside the NASZ propagated westward toward the Aegean domain during the last $5 \mathrm{Ma}$, reaching a bulk offset of $85 \mathrm{~km}$ (Armijo et al., 1999; HubertFerrari et al., 2003; Sengör et al., 2005).

On the other hand, Aegean back-arc extension that is driven by slab rollback started around $45 \mathrm{Ma}$ ago (Brun and Sokoutis, 2010) and accommodated approximately $700 \mathrm{~km}$ of trench retreat (Jolivet and Brun, 2010; Jolivet et al., 2013). Extension followed the closure, in Cretaceous-Eocene, of two oceanic domains of Vardar and Pindos, leading to the stacking of three continental blocks that are from top to base: Rhodopia, Pelagonia and Adria (Fig. 1b). Various seismic tomographic images of the underlying mantle display a single slab (e.g. Wortel and Spakman, 2000; Piromallo and Morelli, 2003; Widiyantoro et al., 2004) indicating that the convergence of continental blocks, which are separated by two suture zones, has been accommodated by a single subduction. During subduction rollback, Pelagonia and Adria crust panels were fully detached from the downgoing lithospheric mantle and moved back to surface, resting directly on top of asthenosphere (Brun and Faccenna, 2008). The recent restoration of dominantly brittle deformations that segmented the metamorphic units of the Cyclades (Philippon et al., 2012) showed that a component of EW shortening started to interfere with NS extension in late Miocene. This suggests that the westward displacement of Anatolia is not only recorded in the NAF-NASZ but that it also affected the central Aegean since late Miocene. 
The purpose of the present study is to test this hypothesis by modelling the interaction between back-arc extension and Anatolia escape. In this perspective, the Aegean tectonic history, as briefly summarized above, is of first order importance and has direct implications on our modelling strategy. First, the displacements related to back-arc extension and strikeslip shear along the NAF-NASZ differ by one order of magnitude (From $700 \mathrm{~km}$ compared to $85 \mathrm{~km}$ ) and their duration by a factor three-four (From 45 to $13 \mathrm{Ma}$ ). Second, the continental crust of Pelagonia and Adria has been delaminated from the downgoing lithospheric mantle during subduction, -see cross-section, Fig. 1c and Jolivet and Brun (2010)- leading to a thin and weak Aegean lithosphere since Eocene. Third, the suture zones that separate the three continental blocks were potential mechanical discontinuities in the extending system. This is suggested in particular by the Vardar Suture Zone (VSZ) that is, at regional scale (Fig.1), a striking geological and morphological discontinuity that separates the northern from the southern parts of the Aegean. Thus, the present investigation addresses the interaction between back-arc extension and Anatolia escape as a function of: i) the relative timing and rates of trench retreat and Anatolia escape and ii) the rheology of the Aegean domain including heterogeneities inherited from the previous tectonic events.

\section{Aegean extension}

\subsection{A two-stage history}

During the three last decades, successive improvements in understanding of deformation processes that accommodate back arc extension in the Aegean has lead to revise the age of the onset of extension roughly from 15 to $45 \mathrm{Ma}$ : i) Mid-Miocene (around $15 \mathrm{Ma}$ ) from faulting in sedimentary basins (Mercier, 1977; Angelier and Le Pichon, 1980); ii) Late Oligocene (30 Ma) from metamorphic core complexes in the central Cyclades (Lister et al., 
1984; Gautier et al., 1993); iii) Early to Middle-Eocene (around $45 \mathrm{Ma}$ ) from normal faulting that controls sedimentary basins (Burchfiel et al., 2003) and metamorphic core complexes (Sokoutis et al., 1993; Bonev et al., 2006; Brun and Sokoutis 2007) in the Rhodope as well as from exhumation of high pressure metamorphic rocks driven by slab rollback in the Cyclades (Brun and Faccenna 2008). As recognized in the earlier plate kinematic models of the region, the NAF has been preceded by a larger zone of displacement -Called "Proto-Anatolian Transform" by (Dewey and Sengör 1979)- initiating in late Miocene and connected to the Bitlis suture in eastern Anatolia. More recent work (Sengör et al., 2005) brought quantitative arguments showing that the NAF resulted from strain localisation within the $100 \mathrm{~km}$ wide NASZ. This indicates that the interaction between back-arc extension and Anatolia westward displacement roughly concerns the last $13 \mathrm{Ma}$ of the Aegean tectonic history, following around $30 \mathrm{Ma}$ of only back-arc extension driven by slab rollback. It is therefore appropriate to describe Aegean extension as a two-stage process (Fig.2).

From mid-Eocene (45 Ma) to middle Miocene (around $13 \mathrm{Ma}$ ), the velocity of trench retreat was likely lower than $1.0 \mathrm{~cm} \mathrm{y}^{-1}$ (Brun and Sokoutis, 2010) and extension was dominantly accommodated by the exhumation of metamorphic rocks in i) high-pressure (HP) metamorphic belts to the south of the Vardar Suture Zone (VSZ) (see synthesis of available data in Fig. 5 of Philippon et al., 2012), and ii) high temperature (HT) metamorphic core complex in the Rhodope (Brun and Sokoutis, 2007) and in the Cyclades (Lister et al., 1984; Gautier et al., 1993) (Fig.2, stage 1). Note that exhumation of HT metamorphic rocks in the Cyclades and exhumation of HP metamorphic rocks in Crete-Peloponnese are coeval. The VSZ, mostly made of serpentinized ophiolite (Bonneau and Kienast, 1982; Ridley, 1982), separates the Aegean in two domains whose tectonic history and present-day kinematic patterns differ significantly. The suture is well defined in continental Greece, where it strikes NW-SE and in Turkey (Izmir-Ankara) with NE-SW orientation. These two branches of the 
VSZ are linked by the North Cycladic Detachment (NCD) (Jolivet et al., 2010), which accommodated the exhumation of the Central Cyclades Core Complex (CCCC) (Philippon et al., 2012), suggesting a reactivation of the VZS (Figs. 1b and c).

In summary, the first stage of extension (from 45 to 13 Ma; Fig. 2) is accommodated by contrasted modes of deformation to the North (HT core complex) and South of the VSZ (exhumation of HP metamorphic rocks followed by HT core complex). From middle Miocene onward, trench retreat accelerated reaching its present day value of $3.3 \mathrm{~cm} \mathrm{y}^{-1}$ in the southern Hellenic arc (Mc Clusky et al., 2000), leading to the development of extensional basins at the scale of the whole Aegean (Mascle and Martin, 1990)) (Fig.2, stage 2). During this second stage of Aegean extension, Peloponnese rotated about 25 clockwise (cw) (Laj et al., 1982) around a pole located at Kephalonia, whereas Crete (Duermeijer et al., 1998) and Rhodos island (Van Hinsbergen et al., 2007) rotated by more than $20^{\circ}$ counter-clockwise (ccw) around a pole located close to Rhodos (Fig. 1b). These rotations led to the present-day Hellenic arc curvature with trench-parallel strike-slip displacements, dextral to the west and sinistral to the east. This second stage of extension (from 13 Ma to present-day) is thus characterized by distributed deformation that affected the whole upper plate of the Hellenic subduction, from Crete to Rhodope, leading to the segmentation of the metamorphic domains that were exhumed during the first stage.

\subsection{A late Miocene component of EW shortening in Central Aegean}

The tectonic evolution of the central Aegean reveals that coeval EW shortening and NS extension occurred from mid-Miocene to Pliocene (Fig. 3). After the exhumation of blueschists up to crustal level and the development of the CCCC, the dextral strike-slip fault of Myrthes-Ikaria (Philippon et al., 2012), which developed in the prolongation of the VSZ 
branch of western Turkey (Izmir-Ankara Suture), separated the Cyclades in two large domains. The northwestern domain rotated about $22^{\circ} \mathrm{ccw}$ whereas the southeastern domain rotated about $33^{\circ} \mathrm{cw}$ (Morris and Anderson, 1996). As indicated by the age of rotated dykes in Tinos (Avigad et al., 1998) rotations likely occurred after $12 \mathrm{Ma}$,

The dextral offset of the NCD along the fault is in the order of $50 \mathrm{~km}$ (Fig. 3a). In the southeastern block, the detachment zone of Naxos and Paros, as well as its footwall metamorphic units and Burdigalian sediments in its hangingwall in Paros (Angelier, 1977), are affected by upright folds with NS trending axes, defining, with reference to the MyrthesIkaria fault an en échelon pattern compatible with the dextral sense of strike-slip. The folding of the Burdigalian sediments implies that the detachment on which they are deposited (see Fig. 2 in Gautier et al., 1993) is itself deformed after the core complex exhumation. In other words, the N-S elongated shape of the Paros and Naxos domes as well as the strong curvature of the detachment at map scale are not original but due to the superposition of postmetamorphic folding. In the northwestern block, the metamorphic units are affected by a set of normal faults trending parallel to the NCD.

The first mapping of stretching lineations at regional-scale in the Cyclades (Gautier and Brun, 1994) identified two different trends, NE-SW to the northwest and N-S to the southeast, of a NE-SW trending and rather linear discontinuity that was later named "MidCycladic Lineament" (Walcott and White, 1998). Following Philippon et al., 2012, we interpreted this lineament as the Myrthes-Ikaria strike-slip fault. After restoration i) of block rotations and ii) of $50 \mathrm{~km}$ of strike-slip offset along Myrthes-Ikaria fault, the two populations of lineations become parallel in a NNE-SSW direction (Figs. 14 and 15 in Philippon et al., 2012). In addition, the three main segments of detachments that are observed at map scale (Fig. 3a) become a single one after restoration, showing that the Paros-Naxos detachment is not a detachment separated of the NCD but part it. 
At the scale of the whole Cyclades, the narrow distribution of low temperature ages (97 measurements) reveals that this post-metamorphic deformation occurred from middle Miocene (14 Ma) to early Pliocene (4Ma) reaching a peak during the Tortonian (8-9 Ma) (Fig. 3b) -i.e. at the onset of the second stage of Aegean extension (Fig. 2, stage 2). It must be noted that folding of Burdigalian sediments in Paros and rotation of dykes dated at $12 \mathrm{Ma}$ in Tinos are both in agreement with this range of low temperature ages.

This post-metamorphic deformation pattern in Central Aegean resulted from a component of EW shortening, coeval with the on-going NS stretching, confirming that the westward displacement of Anatolia started around 13 Ma. The NE-SW trend of the MyrthesIkaria fault indicates that the Izmir-Ankara Suture (part of the VSZ) was simultaneously reactivated as a dextral strike-slip.

\section{Laboratory modelling}

\subsection{Previous laboratory modelling of Aegean extension}

Two types of laboratory experiments were carried out in the Laboratory of Experimental Tectonics of Géosciences Rennes to model Aegean extension (Fig. 4).

The first type of experiments (Hatzfeld et al., 1997; Gautier et al., 1999) simulates back-arc extension as a pure gravity collapse without any lateral component of displacement that would represent Anatolia escape (Figs. 4a and b). The model consists in a two-layer brittle-ductile (sand-silicone) representing the lithosphere that floats on top of a heavier fluid (honey) representing the asthenosphere. The brittle-ductile assemblage is built in one half of a tank and is separated from the second tank half, containing only honey, by a vertical wall with a mobile central gate. When the mobile gate is removed, the model progressively flows under 
its own weight through the space opened in the wall, as shown in figures $4 \mathrm{a}$ and $\mathrm{b}$. The deformation pattern is symmetrical with respect to the flow direction, at the scale of the deforming domain. During the earlier stages of development (Fig. 4a) the deformation pattern is made of: i) normal faults trending parallel to the flow direction at the front, ii) conjugate strike-slip faults in the central part and iii) conjugate extensional strike-slip faults at the back. During further stages of spreading (Fig. 4b), the front of the spreading model becomes more strongly arcuate with radial normal faults and extension propagates in the central part of the deforming domain reactivating former strike-slip faults in transtension.

The second type of experiments (Martinod et al., 2000) uses, like in type 1 models, a two-layer brittle-ductile system floating on top of a heavy liquid and, therefore, is also able to spread under its own weight. The right part of the model is simultaneously shortened at constant rate by a rigid indenter to simulate the northward motion of the Arabia plate (Figs. 4c and d). Thrust faults develop in the right part of the model to accommodate the convergence of the indenter. Normal faults develop both in the inner part of the southwestward flowing domain as well as at the front of gravity spreading of the model. These contractional and extensional domains are linked by dextral strike-slip faults that control the lateral escape of the deforming domain.

In these two types of experiments, the brittle-ductile two-layer lithosphere is able to flow under its own weight. This is essential to obtain extension over distances equivalent to $800 \mathrm{~km}$ in nature as observed in the Aegean (wide rift mode; for theoretical aspects see Buck (1990) and for laboratory experiments Brun (1999) and Tirel et al. (2006)). Therefore the spreading rate and consequently the stretching rate are purely controlled by the density and thickness of the layers. In back-arc settings, like the Aegean, the stretching rate depends primarily on the velocity of trench retreat. From this point of view, it must be noted that in pure gravity spreading the stretching rate decreases during extension as a direct function of 
thinning of the extending domain whereas in back-arc settings the velocity of trench retreat increases with time, as in the Aegean (Brun and Faccenna, 2008; Brun and Sokoutis, 2010; Jolivet and Brun, 2010). In experiments where the boundary displacement rate is kept constant (e.g. Figs. $7 \mathrm{~b}$ and 10c in Tirel et al., 2006) this can lead to strain localisation allowing the development of a narrow rift in a domain previously deforming in wide rift mode. Therefore, whereas model rheology is adapted to the simulation of back-arc extension in the two types of previous experiments (Fig. 4) the above remarks suggest that taking into account the displacement rates applied at model boundaries -i.e. velocities of trench retreat and of Anatolia escape- is an important condition to quantify the interaction between the two combined processes.

\subsection{Modelling strategy}

For testing the concept of a westward displacement of Anatolia around $10 \mathrm{Ma}$ earlier than usually considered, analogue models were employed to investigate the deformation patterns that result from different combinations, in terms of timing and displacement rate, of a $\mathrm{N}-\mathrm{S}$ extension driven by trench retreat and an E-W shortening driven by Anatolia escape (Fig. 5). The model lithosphere is a two-layer brittle-ductile plate, made of feldspar sand (brittle) and silicone putty mixture (viscous), floating on top of a low viscosity, high-density fluid simulating the lithospheric lower mantle and asthenosphere within a rectangular tank.

To ease comparison between model and nature we adopt geographic coordinates to describe the modelling set up and results. Two saloon-type doors opening in the middle of the southern tank wall are pulled at a constant rate $\mathrm{V}_{\text {retreat }}$ to simulate trench retreat. The axes of door rotation would be located in nature in the vicinity of the Kephalonia fault and Rhodos at the western and eastern ends of the Hellenic arc, respectively (Fig. 1, Fig.5). Anatolia escape 
is simulated by the westward displacement of the eastern lateral wall of the tank at a constant rate $\mathrm{V}_{\text {escape }}$. The eastern rotation axis being attached to the eastern lateral wall also displaces at a rate $\mathrm{V}_{\text {escape. }}$.

Model strength profiles (Fig. 5) depend on the thickness and the density of feldspar sand and silicone putty, the frictional angle of sand, the viscosity of silicone putty and the velocities $\mathrm{V}_{\text {retreat }}$ and $\mathrm{V}_{\text {escape }}$ applied at model boundary (Brun, 1999).

In one of the experiments presented here, the VSZ has been implemented by reducing the initial thickness of the brittle layer to two third within a $1 \mathrm{~cm}$ wide band with a $\mathrm{V}$-shape. This geometry resembles the one already acquired by the VSZ in middle Miocene (Brun and Sokoutis, 2010). However, by keeping the experiments as simple as possible it has some inherent limitations. In particular the models do not take into account neither the Aegean extension that occurred prior to early Miocene nor the one that occurred to the east of the Aegean domain.

\subsection{Modelling techniques and principles}

The experiments have been performed at the ISES TecLab, located now at Utrecht University (ISES stands for the Netherlands Research Centre for Integrated Solid Earth Science). The techniques (apparatus, analogue materials and velocimetry) and scaling principles used to set up the models can be summarized as follow.

Apparatus. The analogue experiments were carried out in an apparatus consisting of a Plexiglas tank (120x60x15cm), in which (i) the "southern wall" consists of two saloon-type doors to simulate the retreating Hellenic subduction and (ii) the right part of the box is a westward moving wall, attached to the right saloon door to simulate the westward escape of 
Anatolia (Fig 5). The size of the box and the geometry of the moving wall match the observed geometry of the Aegean-Anatolian system such as $1 \mathrm{~cm}$ in the model is equivalent to $10 \mathrm{~km}$ in nature. Two motors controlled the velocities of the displacements applied at saloon-type doors (trench retreat) and moving wall (Anatolia escape). During the experiment, the model is not fully contained between the two rotating doors. However, the applied $\mathrm{V}_{\text {retreat }}$ is such that the model does not significantly flow between the doors.

Analogue materials. As previously mentioned, the continental crust of Pelagonia and Adria has been delaminated from the downgoing lithospheric mantle during subduction and was resting directly on top of asthenosphere since Eocene (see cross-section in Fig 1c). Therefore, the Aegean lithosphere submitted to back-arc extension since middle Eocene was thin and weak and can be modelled as a two-layer system as previously done by (Hatzfeld et al., 1997; Gautier et al., 1999; Martinod et al., 2000). Extrapolation of laboratory experiment results assisted the selection of the materials to reproduce the rheological stratification of the lithosphere in the models (Kirby, 1983, 1985; Carter and Tsenn, 1987; Ranalli, 1995, 1997). The brittle crust was simulated by dry K-feldspar sand, whose behaviour is dominantly of Mohr-Coulomb frictional type. A mixture of SGM-36 silicone putty with barium sulphate powder, Rhodorsil and oleic acid was designed to model the ductile part of the lithosphere with quasi-Newtonian behaviour. These layers floated on a low viscosity, high-density fluid that consisted of sodiumpolytungstate solution and glycerol mixture representing the asthenosphere. The physical properties of the experimental materials are listed in Table1.

Scaling. The models were scaled following the principles of geometric and dynamicrheologic similarity (King Hubbert, 1937; Ramberg, 1981; Weijermars and Schmeling, 1986; Brun, 1999; Sokoutis et al., 2005). Rheologic-dynamic similarity between model and nature was established by scaling the gravitational stress $\sigma^{*}=\rho^{*} \mathrm{~g}^{*} 1^{*}$, where $\rho$, g and 1 are the density, the gravitational acceleration and the length, respectively. The asterisk denotes the 
ratio between model and nature. The model parameters were validated by calculating nondimensional numbers given by ratios between forces acting on the models (Ramberg, 1981). For the viscous deformation, the ratio between gravitational and viscous stresses (Ramberg number $\mathrm{R}_{\mathrm{m}}$; Weijermars and Schmeling, 1986) is given by:

$$
\text { (1) } R_{m}=\left(\rho_{d} g h_{d}\right) /(\eta \quad)
$$

Density and thickness of the ductile layer are denoted by $\rho_{d}$, and $h_{d}$, respectively, $g(=$ $9.81 \mathrm{~ms}^{-2}$ ) is the gravitational acceleration, $\eta$ is the viscosity and is the strain rate. The rates of displacement in the model were calibrated according to our present knowledge on the horizontal crustal movements in the Aegean region constrained by the GPS velocity vectors. For scaling brittle deformation, we considered the ratio between gravitational stress and cohesive strength $\left(\mathrm{S}_{\mathrm{m}}\right.$ - Smoluchowski number; Ramberg, 1981):

$$
\text { (2) } S_{m}=\left(\rho_{b} g h_{b}\right) /\left(\tau_{c}+\mu \rho_{b} g h_{b}\right)
$$

Where, $\rho_{b}$ and $h_{b}$ are the density and thickness of the brittle layer, respectively, $g\left(=9.81 \mathrm{~ms}^{-2}\right)$ is the gravitational acceleration, $\tau_{\mathrm{c}}$ is the cohesive strength and $\mu$ is the coefficient of internal friction. In order to make a valid comparison between the model results and the geological processes, the natural prototype and the model must share similar $R_{m}$ and $S_{m}$ values. In the present work, the Ramberg numbers of the model and nature representing the ductile layers are almost identical (Table 1). For the brittle part, the ratio between the Smoluchowski numbers does not deviate much from 1 either (Table 1). The obtained ratios between the dimensionless numbers, characterizing the rheologic-dynamic similarity, demonstrate that the first-order approximations of our models are justifiable and the model results applicable to the evolution of the Aegean. 
Velocity field. The velocity field at a given time $t_{n}$ of the experiment has been obtained by comparing two top views of the model at $t_{n}$ and 15 minutes (e.g. $1 \mathrm{Ma}$ ) before $\left(\mathrm{t}_{\mathrm{n}-15 \mathrm{mn}}\right)$, (using the Particle Image Velocimetry (PIV) technique (Westerweel, 1993), later applied to analogue models by Leever et al. (2011)). For that purpose, black passive markers were spread randomly on top of the model surface.

\section{Parametric study}

To analyse the relative roles of i) the timing of Anatolia escape, ii) the amount of related E-W shortening and iii) the role of structural inheritance (VSZ), we first calibrate the corresponding model parameters, keeping a constant velocity of trench retreat $\left(\mathrm{V}_{\text {retreat }}\right)$ of 5 $\mathrm{cm} \mathrm{h}^{-1}$ and an experiment duration of 5 hours to ease comparison between models.

\subsection{Effects of relative timing of trench retreat and lateral escape}

Three models with different onset of lateral escape with reference to the onset of trench retreat have been run (Fig. 6).

In models where lateral escape and trench retreat start simultaneously (Fig. 6a) three contrasted domains of deformation develop. Extension is localized in the triangle defined by the rotating doors. Extensional structures, which initiate perpendicular to the direction of lateral escape, progressively undergo a component of E-W shortening the extensional structures are folded. A thrust fault trending parallel to the moving wall - i.e. perpendicular to the shortening direction- develops in the northeast part of the model. NE-SW trending strikeslip faults connect the thrusting domain to the western rotation axis. 
In models where lateral escape starts one hour after trench retreat (Fig. 6b), the extensional domain extends to the North of the triangle defined by the rotating doors. Still, a thrusting domain connects to the western rotation axis. Strike-slip faults that connect the thrusting domain to the western rotation axis are shorter.

In models where lateral escape starts three hours after trench retreat (Fig. 6c), the extensional domain is well developed and reaches the first half or/the middle of the tank and the thrusting domain develops in the late stages of the experiment. Two main basins connect the zone of thrusting to the western and eastern rotation axes.

The comparison of these models has two first-order outcomes (Fig. 6). First, the extensional domain is largely developed to the north of the line joining the axes of rotating doors, only if the lateral escape start significantly after the trench retreat. In other terms, lateral escape is an inhibiting factor of extension. Second, whatever the relative timing between trench retreat and lateral escape, the escape component is accommodated in the northern part of the model by a domain of thrusting that is connected to the extensional domain by strike-slip systems. If the extensional domain is largely developed, strike-slip shear reactivates previously developed extensional structures.

\subsection{Effects of the amount of $E-W$ shortening}

The absence of any evidence of N-S trending thrusts in the northern part of the Aegean strongly suggests that E-W shortening due to lateral escape is likely accommodated by the reactivation of structures inherited from previous deformations. Therefore, using the same experimental setting than in previous section, in this section we examine the role i) of the amount of shortening and ii) of inherited structures, able to produce the first-order tectonic features observed in the Aegean domain. 
Two models in which lateral escape starts 3 hours after trench retreat were run during 2 hours at $V_{\text {escape }}$ of $5 \mathrm{~cm} / \mathrm{h}$ and $2 \mathrm{~cm} / \mathrm{h}$, respectively (Figs $7 \mathrm{a}$ and $7 \mathrm{~b}$ ). In both experiments, the extensional domain is well developed, reaching the middle of the tank. E-W shortening is accommodated: i) by thrusting in the northern part of the model that is not affected by extension and ii) by strike-slip shear that reactivate extensional structures or that initiate strike-slip faults (Fig. $7 \mathrm{a}$ and b). The relative importance of thrust and strike-slip deformation in the system directly depends on the amount of lateral escape. For a bulk lateral escape of 10 cm (Fig. 7a), the thrust domain is well developed and the deformation pattern in the North of the model is dominated by thrusts, with limited amount of strike-slip deformation. In contrast, for a bulk lateral escape of $4 \mathrm{~cm}$ (Fig. 7b) leads to limited thrusting, which however still exist, as well as a deformation pattern dominated by strike slip. These results show that whatever the bulk amount of escape, a thrusting domain develops to the north of the experiment.

\subsection{Effects of lithosphere scale inherited structures}

Two models (Figs $7 \mathrm{~b}$ and $7 \mathrm{c}$ ) were run with similar magnitude and timing of $\mathrm{V}_{\text {retreat }}$ and $\mathrm{V}_{\text {escape }}$ but, in the second one, a weak linear heterogeneity was introduced to test the role of inherited structures at lithosphere-scale on the development of deformation.

Whereas several geometries of weak zones were tested, we present here is the most conclusive one (Fig. 7c) as it can be directly compared to a major structure of the Aegean like the Vardar suture zone (VSZ). In this model, thrusting does not develop in the northern domain, which is not affected by compression, and the deformation pattern combines only extensional and strike-slip faulting. The model reproduces the first order structures observed at Aegean scale: i) no thrusting in the northern domain, ii) coeval NS stretching and EW shortening in the central domain (Cyclades). Moreover, after 5 hours of model run, a dextral 
strike-slip fault starts to develop in the northeast corner of the tank that can be compared the North Anatolian Fault (NAF) (Fig. 7c).

\section{A model of Aegean extension since Miocene}

The evolution of deformation in the model that takes into account an inherited structure analogue to the VSZ is summarized in four main steps (Fig. 8). To ease comparison with nature, model timing in hours is also given in their equivalent in Ma (15 minutes in the model corresponds to $1 \mathrm{Ma}$ in nature). During the early stage of pure trench retreat (Fig. 8a) extension develops across the VSZ. The jump in the displacement vectors indicates that the suture is reactivated in transtension in the deformed domain (Fig. 8b). Soon after the onset of lateral escape, the whole eastern branch of the suture zone is activated in dextral strike-slip shear and a strike-slip fault propagates into the southern extensional domain (Fig.8c and d), whose further evolution is associated with N-S trending folds, demonstrating an E-W shortening combined with $\mathrm{N}-\mathrm{S}$ extension (Fig. 8e and f). Whereas displacement vectors show that the eastern part of the domain located to the north of the suture displaces westward no fault appear at model surface. The boundary of this domain likely corresponds to a region of distributed shear (Fig. 8c and d). With increasing lateral escape, a new strike-slip fault running almost parallel to the suture zone initiates in the northeast domain (Fig.8e and f) and rapidly propagates toward the extensional domain (Fig. 8g). Surface views of the model show that stretching is stronger in the triangle located between the two rotating doors (Figs.8a, c, e and $\mathrm{g}$ ). This is also displayed by the strong change in displacement vectors that progressively takes place across to the straight line passing by the two rotation axes (Figs. 8d and f).

\section{Discussion: The interaction between Hellenic trench retreat and Anatolia escape}




\subsection{The record of the onset of Anatolia escape in Central Aegean.}

Despite their simplicity, our experiments reproduce well the overall pattern of Aegean extension, in space and time, and more particularly the structures observed in the central Cyclades. Dextral strike-slip faulting that offset the North Cycladic Detachment (NCS) and associated NNE-SSW trending folding (Compare the enlargement of Figs. 8a and 8g in Fig. 9 with Fig. 3a) indicates a combination of EW shortening with NS stretching. NS trending folds that result from EW shortening are kinematically compatible with NE-SW trending and dextral sense strike-slip shear zone that affect model centre (Fig. 8e), therefore defining an en échelon folding pattern (Fig. 9b). The same hold in the Cyclades for NNE-SSW trending axes of the folds that deform the detachment of Paros-Naxos in their relation with the MyrthesIkaria dextral strike-slip fault.

This deformation that culminates during Tortonian (Fig. 3b) in the Cyclades suggests a reactivation of the Izmir-Ankara branch of the Vardar suture zone in dextral strike-slip shear in western Anatolia. This tectonic event recorded in Central Aegean corresponds to the major change observed in the history of Aegean extension in middle Miocene (Fig. 2). It is difficult to state when this change precisely started. The peak of surface dating is Tortonian but the first deformations related to the Cyclades segmentation have likely occurred in Langhian, i.e. between 14 and $13 \mathrm{Ma}$ (Fig. 3b). In our model (Fig. 8) we choose $13 \mathrm{Ma}$ as a reasonable option. Whatever the uncertainty, the Cyclades evidence indicates that the early domain of deformation related to the westward displacement of Anatolia was not restricted to the northern part of Anatolia within the NASZ but that it more likely concerned an even broader wedge shape zone bound by the Izmir-Ankara Suture to the south and the NASZ to the north. Both the timing and the dextral sense of shear observed in the Cyclades are supported by the 
age of $15 \mathrm{Ma}$ for continental collision in eastern Anatolia (Zattin et al., 2005; Okay et al., 2010) and by the evidences of distributed dextral shear that precedes the localisation of the NAF in northwest Anatolia (Bozkurt and Oberhänsli, 2001; Sengör et al., 2005; Zattin et al., 2005; Okay et al., 2008).

\subsection{Ma to present day strain history of the Aegean}

Aegean extension occurred in a first stage of extension only driven by the southward retreat of the Hellenic trench at a low rate of less than $1 \mathrm{~cm} \cdot \mathrm{y}^{-1}$, from middle Eocene to middle Miocene, and a second stage during which slab rollback continues but combined with the westward displacement of Anatolia, since middle Miocene. Our series of experiments illustrate the end of the first stage and the entire second stage. During the second stage, the direction of displacement, in the southern part of the deforming domain, rotated to southwest, as a consequence of the lateral escape of Anatolia, as illustrated by the change in the velocity pattern of the model (Compare Fig. 8b with Figs. 8d and f). The increase in the rate of trench retreat up to more than $3 \mathrm{~cm} \cdot \mathrm{y}^{-1}$ during this second stage was most likely related to the tearing of the slab in western Anatolia (Fig. 1a) (Brun and Sokoutis, 2010), that is demonstrated by a relatively pronounced lateral break in the continuity of the high velocity anomaly in P-wave models of the Hellenic slab (Wortel and Spakman, 2000; Piromallo and Morelli, 2003; Berk Biryol et al., 2011). Extension was dominantly accommodated by the exhumation of HP rocks and HT core complexes during the first stage (Brun and Faccenna, 2008; Jolivet and Brun 2010) whereas the previously exhumed metamorphic rocks are segmented by normal and strike-slip faults associated to a widespread development of sedimentary basins during the second stage (Philippon et al., 2012). This two-stage history of Aegean extension likely resulted from plate tectonic re-organisation at regional scale, from Late Miocene to Early Pliocene, and could result from slab break-off in the Bitlis area and from its propagation to 
the west (Faccenna et al., 2006).

\subsection{The present-day displacement field}

Finally, the model not only provides a simple scenario for the history of interaction between trench retreat and Anatolia escape since middle Miocene but also explains the present-day partitioning of the displacement field (Fig.8a) with the five kinematics domains identified by Nyst and Thatcher (2004) from North to south: 1) Eurasia, 2) South Marmara, 3) Anatolia, 4) Aegean and 5) Greece (Fig. 5). Nowadays, the major part of Anatolia escape occurs along the NAF, leading to a fixed Eurasia (domain 1 in Fig.8a). The competing effect of trench retreat and Anatolia escape, as demonstrated in our model (Fig. 8b), allows the identification of an eastern domain mainly controlled by Anatolia escape (South Marmara and Anatolia, domains 2 and 3 in Fig. 8) and a western domain mainly controlled by trench retreat (Aegean and Greece, domains 4 and 5 in Fig. 8). The VSZ separates south Marmara and Anatolia. Its strike-slip reactivation likely explains the differences displayed in GPS displacement field.

During trench retreat, rotation around the Kephalonia pole controls the westward decrease of displacement and hence the difference between Aegean and Greece blocks (Domains 4 and 5 in Fig.8). Similarly, rotation around the Rhodos pole likely explains the boundary between Anatolia and the Aegean.

Our analogue model (Fig. 8b) provides a mechanical meaning to the present day displacement field. The so-called "microplates" rather correspond to domains of strain partitioning within the whole extending domain as a result of the competing effects of trench retreat, Anatolia escape and reactivation of the Vardar suture zone. 


\section{Conclusion}

For properly understanding the dynamics of Aegean extension, two main stages must be considered: i) during $30 \mathrm{Ma}$, from middle Eocene to middle Miocene, extension was only driven by the southward retreat of the Hellenic trench at a rate lower than $1 \mathrm{~cm} \cdot \mathrm{y}^{-1}$ and ii) during the last $13 \mathrm{Ma}$, since middle Miocene, the interaction of trench retreat with Anatolia escape resulted in the southwest direction of trench retreat, with an accelerating rate of up to 3 cm. $\mathrm{y}^{-1}$. Using laboratory models, we tested the effects of i) the relative timing and rates of trench retreat and Anatolia escape and ii) the major structures inherited from previous tectonic evolution on the mechanics of Aegean extension.

A model that combines trench retreat and Anatolia escape since 13 Ma together with the reactivation of the inherited Vardar suture zone:

a. Well reproduces middle-late Miocene structures observed in the central Aegean (Cyclades) (Philippon et al., 2012) with, in particular, regional-scale dextral strikeslip faulting associated to NS trending folding, as a result of combined NS stretching and EW shortening, driven by southward trench retreat and Anatolia westward escape, respectively. This confirms that Anatolia started to move westward in middle Miocene (Dewey and Sengör 2004) and suggests that the structural effects of Anatolia escape initially affected a broad domain from North Anatolia and North Aegean to Central Aegean.

b. Shows the development of a dextral strike-slip fault, comparable to the North Anatolian fault, at a late stage of interaction between trench retreat and Anatolia escape, in agreement with the tectonic history of the North Anatolian Shear Zone since middle Miocene (Sengör et al 2004) and the localisation and westward propagation of the North Anatolian Fault during the last 5 Ma (Armijo et al 1999). 
c. Illustrates that the domains distribution of present-day displacements (GPS) corresponds to a partitioning of displacements and strains controlled by the combination of NS trench retreat, E-W Anatolia escape and the reactivation of the Vardar suture zone. 


\section{Acknowledgements}

The authors thank Prof E. Burov, Jospeph Martinod and Loïc Labrousse for pertinent and constructive criticism. The ANR EGEO, directed by Prof. L. Jolivet, has financially supported this work. The authors warmly thank Stephane Mazzotti, Endrè Dombradi and Ernst Willingshofer for their suggestions on an early version of the manuscript. M. Philippon personally thanks Prof. S. Cloetingh and the TecLab Team for their support during the experimental work. D. Sokoutis acknowledges the financial support from the Netherlands Research Centre for Integrated Solid Earth Science (ISES). 


\section{References}

Angelier, J., 1977. Essai sur la néotectonique et les derniers stades tardi-tectoniques de l'arc Egéen et de l'Egée méridionale. B. Soc. Geol. Fr. XIX (3), 651-662.

Angelier, J., Le Pichon, X., 1980. Neotectonique horizontale et verticale de l'Egée: subduction et expansion. Aubouin, J. Debelmas and M. Latreille (Coordinators), Géologie des Chaînes Alpines Issues de la Téthys. Int. Geol. Congr. 26th. Paris, Mém. BRGM 115, 249-260.

Armijo, R., Meyer, B., Hubert, A., Barka, A., 1999. Westward propagation of the north Anatolian into the northern Aegean: timing and kinematics. Geology 27, 267-270.

Avigad, D., Baer, G., Heimann, A., 1998. Block rotations and continental extension in the central Aegean Sea: palaeomagnetic and structural evidence from Tinos and Mykonos (Cyclades, Greece). Earth and Planetary Science Letters 157, 23-40.

Berk Biryol C., Beck, S.L., Zandt, G., Özacar, A.A., 2011. Segmented African lithosphere beneath the Anatolian region inferred from teleseismic P-wave tomography. Geophys. J. Int. 184, 1037-1057.

Bonev, N., 2006. Cenozoic tectonic evolution of the eastern Rhodope massif (Bulgaria): Basement structure and kinematics of syn-to postcollisional extensional deformation. Postcollisional tectonics and magmatism in the Mediterranean region and Asia 409, 211.

Bonneau, M.B., Kienast, J.R., 1982. Subduction, collision et schistes bleus: exemple de l'Egée, Grèce. B. Soc. Geol. Fr. 7, 785-791.

Bozkurt, E., Oberhänsli, R., 2001. Menderes Massif (Western Turkey): structural, metamorphic and magmatic evolution - a synthesis. Int. J. Earth Sciences 89, 679-708.

Buck, W. R., 1990. Comment on "Origin of regional, rooted low-angle normal faults: A mechanical model and its tectonic implications" by An Yin. Tectonics 9, 545-546, 
doi:10.1029/TC009i003p00545.

Brun, J.P., 1999. Narrow rifts versus wide rifts: Inferences for the mechanics of rifting from laboratory experiments. Philos. Trans. R. Soc. London, Ser. A 357, 695- 712.

Brun, J.P., Faccenna, C., 2008. Exhumation of high-pressure rocks driven by slab rollback. Earth Planet. Sci. Lett. 272, 1-7.

Brun, J.P., Sokoutis D., 2007. Kinematics of the Southern Rhodope Core Complex (north Greece). Int. J. Earth Sci. 96, 1079-1099.

Brun J.P., Sokoutis D., 2010. 45 Ma of Aegean crust and mantle flow driven by trench retreat. Geology 38, 815-818.

Burchfiel, B.C., Nakov, R., Tzankov, T., 2003. Evidence from the Mesta half-graben, SW Bulgaria, for the late Eocene beginning of Aegean extension in the Central Balkan Peninsula. Tectonophysics $375,61-76$

Carter, N.L., Tsenn, M.C., 1987. Flow properties of continental lithosphere. Tectonophysics $136,27-63$.

Dewey, J. F., Şengör, A. C., 1979. Aegean and surrounding regions: complex multiplate and continuum tectonics in a convergent zone. Geol. Soc. Am. Bull. 90, 84-92.

Duermeijer, C.E., Krijgsman, W., Langereis, C.G., Ten Veen, J.H., 1998. Post early Messinian counter-clockwise rotations on Crete: implications for the late Miocene to Recent kinematics of the southern Hellenic Arc. Tectonophysics 298, 177-189.

Faccenna C., Bellier, O., Martinod, J., Piromallo C., Regard, V., 2006. Slab detachment beneath eastern Anatolia: A possible cause for the formation of the North Anatolian fault. Earth Planet. Sci. Lett. 242, 85- 97.

Gautier, P., Brun, J.P., 1994. Ductile crust exhumation and extensional detachments in the central Aegean (Cyclades and Evvia islands). Geodinamica Acta 7, 57-85.

Gautier, P., Brun J-P., Jolivet, L. 1993 Structure and kinematics of upper cenozoic 
extensional detachment on Naxos and Paros (Cyclades Islands, Greece). Tectonics, 12, 1180-1194.

Gautier, P., Brun, J. P., Moriceau, R., Sokoutis, D., Martinod, J., Jolivet, L., 1999. Timing, kinematics and cause of Aegean extension: a scenario based on a comparison with simple analogue experiments. Tectonophysics 315, 31-72.

Hatzfeld, D., Martinod, J., Bastet, G., Gautier, P., 1997. An analog experiment for the Aegean to describe the contribution of gravitational potential energy. J. Geophys. Res.: Solid Earth 102(B1), 649-659.

Hubert-Ferrari, A., King, G., Manighetti, I., Armijo, R., Meyer, B., Tapponnier, P., 2003. Long-term Elasticity in the Continental Lithosphere; Modelling the Aden Ridge Propagation and the Anatolian Extrusion Process. Geophys. J. Int. 153, 111-132.

Jolivet, L., Brun, J.P., 2010. Cenozoic geodynamic evolution of the Aegean. Int. J. Earth Sci. 99, 109-138.

Jolivet, L., Lecomte, L., Huet, B., Denèle, Y., Lacombe, O., Labrousse, L., Le Pourhiet, L., Mehl, C., 2010. The North Cycladic Detachment System. Earth Planet. Sci. Lett. 289, 87-104.

Jolivet, L., Faccenna, C., Huet, B., Labrousse, L., Le Pourhiet, L., Lacombe, O., Lecomte, E., Burov, E., Denèle, Y., Brun, J.P., Philippon, M., Paul, A., Salaün, G., Karabulut, H., Piromallo, C., Monié, P., Gueydan, F., Okay, A.I., Oberhänsli, R., Pourteau, A., Augier, R., Gadenne, L., Driussi, O., 2013. Aegean tectonics: Strain localisation, slab tearing and trench retreat. Tectonophysics 597, 1-33. doi:10.1016/j.tecto.2012.06.011

King Hubbert, M., 1937. Theory of scale models as applied to the study of geologic structures. Geol. Soc. Am. Bull. 48, 1459-1519.

Kirby, S.H., 1983. Rheology of the lithosphere. Reviews of Geophysics 21, 1458-1487.

Kirby, S.H., 1985. Rock mechanics observations pertinent to the rheology of the continental 
lithosphere and the localization of strain along shear zones. Tectonophysics 119, 1-27.

Laj, C., Jamet, M., Sorel, D., Valente, J.P., 1982. First paleomagnetic results from the MioPliocene Series of the Hellenic sedimentary arc. Tectonophysics 86, 45-67.

Le Pichon, X., Angelier, J., 1981. The Aegean Sea. Philos. Trans. R. Soc. London, Ser. A $300,357-372$.

Leever, K.A., Gabrielsen, R.H., Sokoutis, D., Willingshofer, E., 2011. The effect of convergence angle on the kinematic evolution of strain partitioning in transpressional brittle wedges: Insight from analog modeling and high-resolution digital image analysis. Tectonics 30, doi: 10.1029/2010TC002823.

Lister, G.S., Banga, G., Feenstra, A., 1984. Metamorphic core complexes of Cordilleran type in the Cyclades, Aegean Sea, Greece. Geology 12, 221-225.

Martinod, J., Hatzfeld, D., Brun, J. P., Davy, P., Gautier, P., 2000. Continental collision, gravity spreading, and kinematics of Aegea and Anatolia. Tectonics 19, 290-299.

Mascle, J., Martin, L., 1990. Shallow structure and recent evolution of the Aegean Sea: a synthesis based on continuous reflection profiles. Marine Geology 94, 271-299.

McClusky, S., Balassanian, S., Barka, A., Demir, C., Ergintav, S., Georgiev, I., Gurkan, O., Hamburger, M., Hurst, K., Kahle, H., Kastens, K., Kekelidze, G., King, R., Kotzev, V., Lenk, O., Mahmoud, S., Mishin, A., Nadariya, M., Ouzounis, A., Paradissis, D., Peter, Y., Prilepin, M., Reilinger, R., Sanli, I., Seeger, H., Tealeb, A., Toksöz, M. N., Veis G., 2000. Global Positioning System constraints on plate kinematics and dynamics in the eastern Mediterranean and Caucasus. J. Geophys. Res. 105, 5695-5719.

McKenzie, D., 1972. Active tectonics of the Mediterranean region. Geophys. J. Roy. Astr. S. 30, 109-185.

McKenzie, D. P., 1978. Active tectonics of the Alpine Himalayan Belt, the Aegean Sea and surrounding regions. Geophys. J. Roy. Astr. S. 55, 217-252. 
Mercier, J., 1977. Principal results of a neotectonic study of the Aegean arc and its location within the eastern Mediterranean. Proc. VI Coll. Geol. Aegean Region, Athens, 12811291.

Morris, A., Anderson, M., 1996. First palaeomagnetic results from the Cycladic Massif, Greece, and their implications for Miocene extension directions and tectonic models in the Aegean. Earth Planet. Sci. Lett. 142, 397-408.

Nyst, M., Thatcher, W., 2004. New constraints on the active tectonic deformation of the Aegean. J. Geophys. Res. 109, B11406, doi:10.1029/2003JB002830

Okay, A.I., Özcan, E.R.C.A.N., Cavazza, W., Okay, N., Less, G., 2010. Basement Types, Lower Eocene Series, Upper Eocene Olistostromes and the Initiation of the Southern Thrace Basin, NW Turkey. Turkish J. Earth Sci. 19, 1-25.

Okay, A.I., Satir, M., Zattin, M., Cavazza, W., Topuz, G., 2008. An Oligocene ductile strikeslip shear zone: Uludağ Massif, northwest Turkey - implications for the escape tectonics. Geol. Soc. Am. Bull. 120, 893-911.

Philippon, M., Brun, J.P., Gueydan F., 2012. Deciphering subduction from exhumation in the segmented Cycladic Blueschist Unit (Central Aegean, Greece). Tectonophysics 524, 116-134.

Piromallo, C., Morelli, A., 2003. P wave tomography of the mantle under the AlpineMediterranean area. J. Geophys. Res. 108(B2), 2065.

Rabaute, A., Chamot-Rooke N., 2007. Quantitative mapping of active mud volcanism at the western Mediterranean Ridge-backstop contact. Mar. Geophys. Res. 28, 271-295.

Ramberg, H., 1981. Gravity, Deformation, And The Earth's Crust: In Theory, Experiments, And Geological Application, 2nd Revised edition ed. Academic Press Inc., London Ranalli, G., 1995.Rheology Of The Earth, 2nd ed., Springer, Berlin Heidelberg. Ranalli, G., 1997. Rheology of the lithosphere in space and time, in: Burg, J.P. and Ford, M. 
(Eds), Orogeny Through Time. Geological Society Special Publications 121, London, pp. 19-37.

Ridley, J., 1982. Arcuate lineation trends in a deep level, ductile thrust belt, Syros, Greece. Tectonophysics 88, 347-360.

Sengör, A.M.C. Tüysüz, O., Imren, C., Sakınç, M., Eyidogan, H., Görür, N., Le Pichon, X., Rangin, C., 2005. The North Anatolian Fault: A New Look. Annu. Rev. Earth Planet. Sci. 33, 37-112.

Sokoutis, D., Brun, J. P., Van Den Driessche, J., Pavlides, S., 1993. A major Oligo-Miocene detachment in southern Rhodope controlling north Aegean extension. J. Geol. Soc. London 150, 243-246.

Sokoutis, D, Burg, J. P., Bonini, M., Corti, G., Cloetingh, S., 2005. Lithospheric-scale structures from the perspective of analogue continental collision. Tectonophysics 406, $1-15$.

Tirel, C., Gueydan, F., Tiberi, C., Brun, J.P., 2004. Aegean crustal thickness inferred from gravity inversion. Geodynamical implications. Earth Planet. Sci. Lett. 228, 267-280.

Tirel, C., Brun, J.P., Sokoutis, D., 2006. Extension of thickened and hot lithospheres, inferences from laboratory modeling. Tectonics 25, doi:10.1029/2005TC001804

Van Hinsbergen, D.J.J., Krijgsman, W., Langereis, C. G., Cornée, J. J., Duermeijer, C. E., Van Vugt, N., 2007. Discrete Plio-Pleistocene phases of tilting and counterclockwise rotation in the southeastern Aegean arc (Rhodos; Greece): early Pliocene formation of the south Aegean left-lateral strike-slip system. J. Geol. Soc. London 164, 1133-1144.

Walcott, C.R., White, S.H., 1998. Constraints on the kinematics of post-orogenic extension imposed by stretching lineations in the Aegean region. Tectonophysics 298, 155-175. doi:10.1016/S0040-1951(98)00182-6.

Weijermars, R., Schmeling, H., 1986. Scaling of Newtonian and non-Newtonian fluid 
dynamics without inertia for quantitative modelling of rock flow due to gravity (including the concept of rheological similarity). Phys. Earth Planet. In. 43, 316-330.

Westerweel, J. 1993. Digital particle image velocimetry, Ph.D. thesis, 237 pp., Delft Univ. of Technol., Delft, Netherlands.

Widiyantoro, S., Van Der Hilst, R. D., Wenzel, F., 2004. Deformation of the Aegean slab in the mantle transition zone. International Journal of Tomography \& Statistics D, 4, 1-14.

Wortel, M.J.R. Spakman, W., 2000. Subduction and slab detachment in the MediterraneanCarpathian region. Science 290, 1910-1917.

Zattin, M., Okay, A. I., \& Cavazza, W., 2005. Fission-track evidence for late Oligocene and mid-Miocene activity along the North Anatolian fault in south-western Thrace. Terra Nova 17, 95-101. 


\section{Figure captions}

Fig. 1 a) Map of the of Aegean domain with present-day displacement rates (GPS) (Vectors from McClusky et al. (2000). The large grey arrows give the present day westward displacement of Anatolia as well as the direction of trench retreat respectively. b) Map of the Aegean domain showing the three main continental units of Rhodopia, Pelagonia and Adria, separated by the two suture zones of Vardar-Izmir-Ankara and Pindos, and the main detachments. NCD stands for North Cycladic Detachment. The geometry of both the Hellenic trench and the Mediterranean Ridge are drawn after Rabaute and Chamot-Rooke (2007). c) Cross-section showing the crustal-scale structure of the Aegean. See location in Fig. 1b. The Moho geometry is based on the computation of Tirel et al. (2004).

Fig. 2 Map view restoration showing the two-stage evolution of Aegean extension (Modified after Brun and Sokoutis (2010). The blue and green boxes indicate the timing of the exhumation of high pressure and high temperature metamorphic rocks. The yellow box indicates the timing of the distributed brittle deformation affecting the whole Aegean.

Fig. 3 a) Present-day bathymetry map of the central Aegean. The Myrthes-Ikaria strike-slip fault (MIF), separates two blocks that underwent rotations of $22^{\circ}$ sinistral to the $\mathrm{NW}$ and $33^{\circ}$ dextral to the SE. The stretching lineations (black and white arrows) acquired by the metamorphic rocks during their burial and exhumation are ante faulting, and trend $\mathrm{NE}$ in the NW block and NS in the SE block respectively. Folding with NNE-SSW trending axes results from dextral strike-slip shear movement in the vicinity of the MIF. b) Frequency distribution histogram of low-temperature thermochronology ages (Apatite and zircon fission tracks as well as $\mathrm{U} / \mathrm{Th} / \mathrm{He}$ on apatite and zircon. Numbers correspond to the frequency of ages within a bin. For further details, see Philippon et al., 2012. 
Fig. 4 Previous analogue models of Aegean extension. a and b) two stages of a pure gravity spreading model (Modified after Hatzfeld et al., 1997; see also Gautier et al., 1999). c and d) two stages of a model combining gravity spreading and shortening in the right part of the model (Modified after Martinod et al., 2000).

Fig. 5 3D sketch of experimental setting and strength profile of the analogue lithosphere used to run experiments with various input parameters. See text and table 1 for materials used and rheological layering. The strength profiles represent the very initial deformation stage calculated using a pure shear strain rate approach $\left(\sigma_{1-} \sigma_{3}=\eta \dot{\varepsilon}\right.$, where $\eta$ is the $\square$ viscosity and $\dot{\varepsilon}$ the strain rate) for the ductile layers (Ramberg 1980) and the Mohr-Coulomb criterion $\left(\sigma_{1-}\right.$ $\sigma_{3}=\mu \rho g z$; where $\rho$ and $\mathrm{z}$ are the density and thickness of the brittle layer, respectively, $\mathrm{g}$ is the gravity acceleration) for brittle layers (Brun, 2002). By $\mathrm{V}_{\text {escape }}$ we refer to the westward movement of Anatolia while $\mathrm{V}_{\text {retreat }}$ represents the trench retreat.

Fig. 6 Top views of three models and their structural interpretation with different timing of onset for the Anatolia escape with reference to trench retreat with $V_{\text {retreat }}=5 \mathrm{~cm} / \mathrm{h}$ and a total duration of the experiment of 5 hours. a) Synchronous lateral escape and trench retreat b) Lateral escape starting 1 hour after trench retreat and c) Lateral escape starting 3 hours after trench retreat.

Fig. 7 Top views of three models and their structural interpretation with different amounts of lateral escape with reference to trench retreat; with $\mathrm{V}_{\text {retreat }}=5 \mathrm{~cm} / \mathrm{h}$, and a 5 hours total duration of the experiments. Amounts of lateral escape: $10 \mathrm{~cm}$ (a) and $4 \mathrm{~cm}$ (b and c). In c, the initial thickness of the upper brittle layer is reduced to two third of its original thickness within a $1 \mathrm{~cm}$ wide band with a $\mathrm{V}$-shape to simulate an inherited structure comparable to the Vardar Suture Zone in the Aegean in Miocene. 
Fig. 8 Evolution in four steps of the experiment shown in Figure 7c. The left column shows model top views with the structural pattern while the right column displays the corresponding velocity field: $\mathrm{a}$ and b) after $2 \mathrm{~h} 15$ of retreat only, c and d) after $3 \mathrm{~h} 15$, i.e. 15 minutes after the onset of lateral escape, e and f) after 5h15, and g) at 6h15, end of experiment. For each step, the geological time corresponding to experiment duration is given in Ma.

Fig. 9 Enlargements of the central part of model top views of Figs. 8a (a) and 8g (b). a) Extensional structures after $2 \mathrm{~h} 15 \mathrm{mn}$ (or $16 \mathrm{Ma}$ ) of NS extension only driven by trench retreat. b) Structure of the same domain after 4 h (or present day). It has combined NS extension (driven by trench retreat) and EW shortening (driven by lateral escape).

Fig. 10 Comparison between the velocity domains in the Aegean (Modified after Nyst and Tatcher (2004)) (a) and in our experiment (Fig. 7) (b). The model fairly replicates the five velocity domains of the Aegean defined by Nyst and Tatcher (2004): 1) Eurasia (fixed), 2) South Marmara, 3) Anatolia, 4) Aegean and 5) Greece, as a result of the interplay of trench retreat, Anatolia escape and suture reactivation since $15 \mathrm{Ma} . \mathrm{NAF}=$ North Anatolian Fault, $\mathrm{VSZ}=$ Vardar Suture Zone.

\section{Table caption}

Tab. 1 Summary of the model parameters and their natural equivalents, including physical properties of analogue materials and scaling parameters of analogue experiments. 

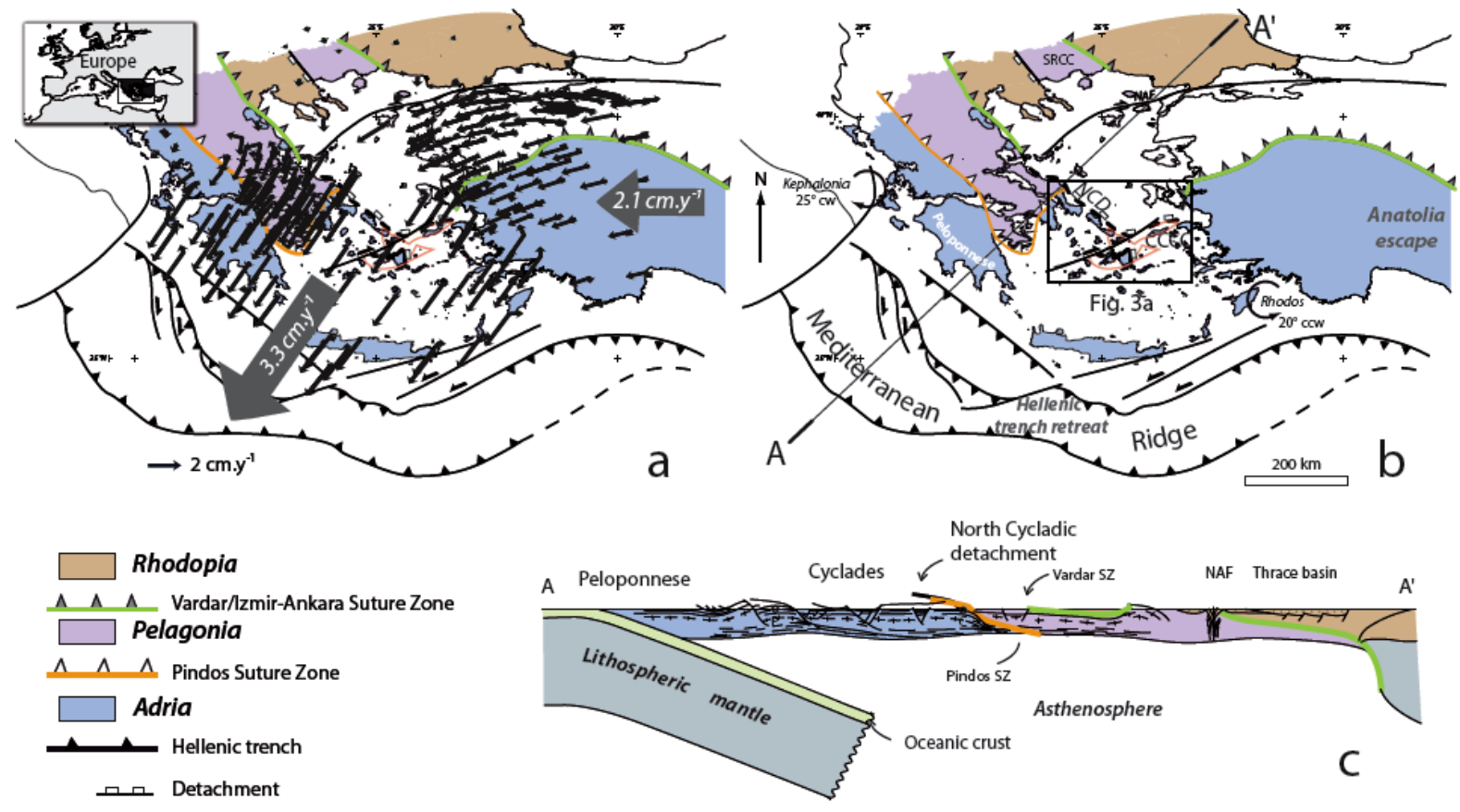

Figure 1 

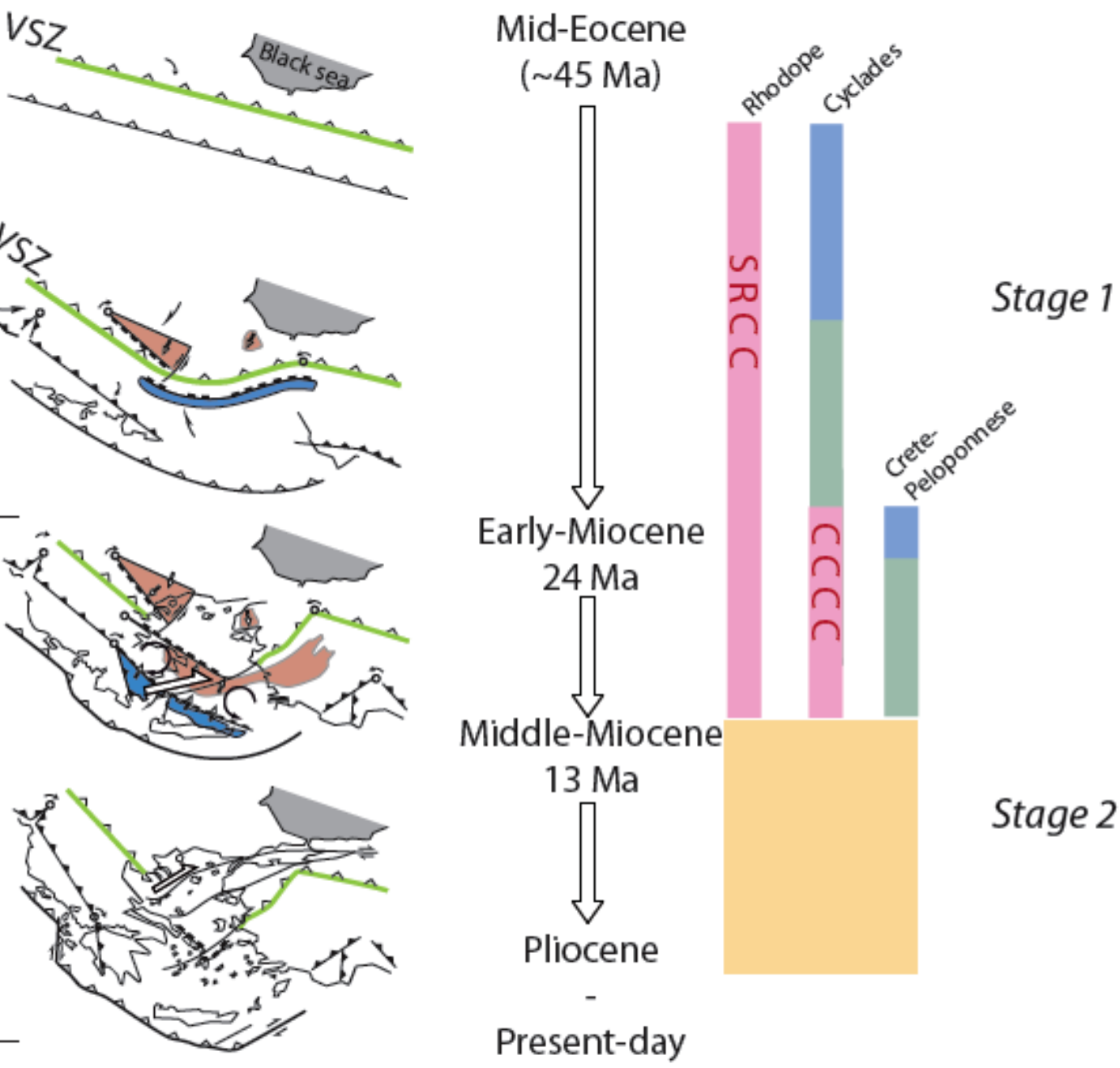

Exhumation of high pressure rocks

Blue: Blueschists facies

Green: Greenschists facies

Exhumation of metamorphic core complexes

Distributed deformation and widespread deposition of Neogene basins. Segmentation of blueschists belts and core complexes

○ Rotation axis with sense of rotation

Figure 2 

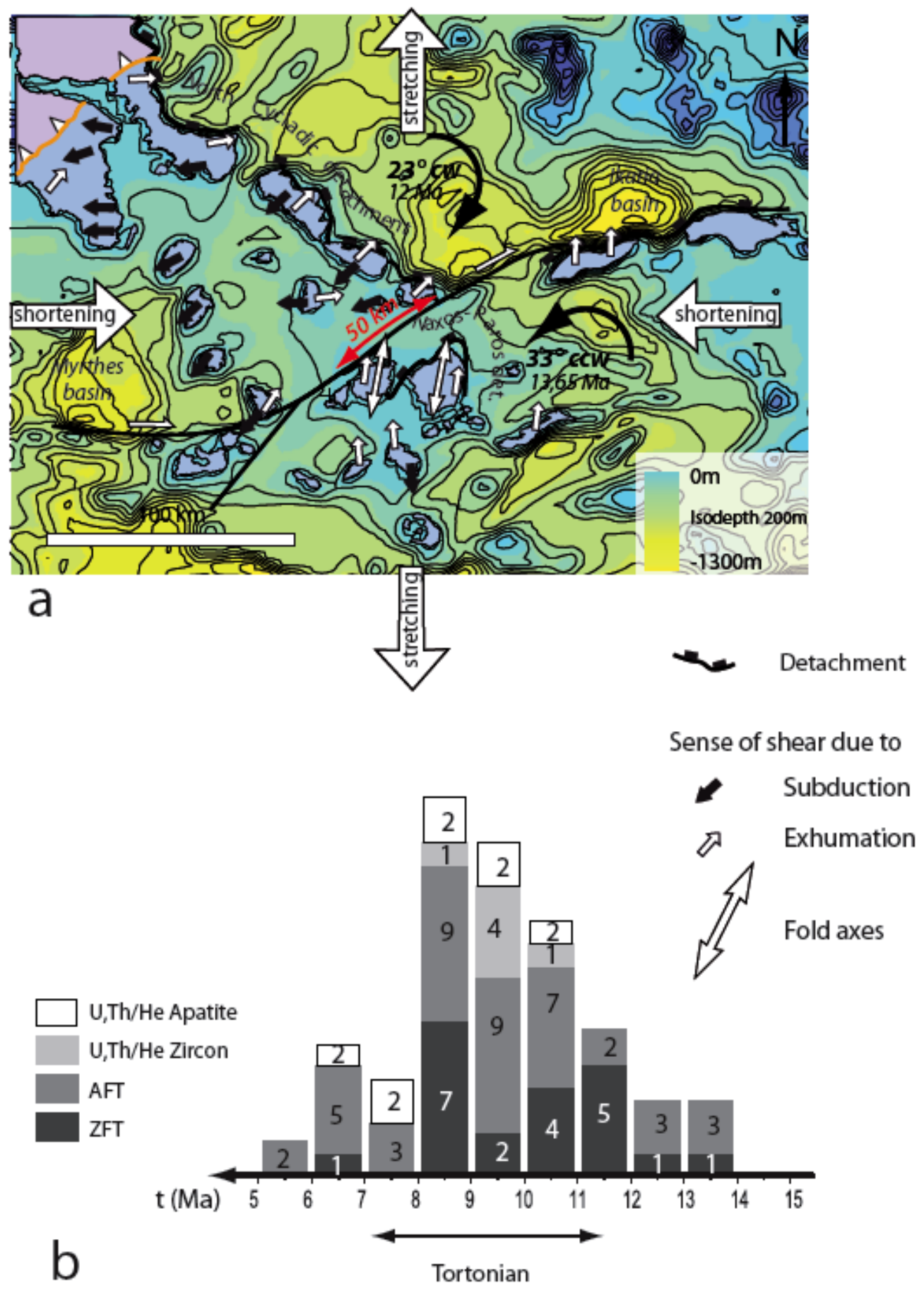

Figure 3 
Gravitational collapse

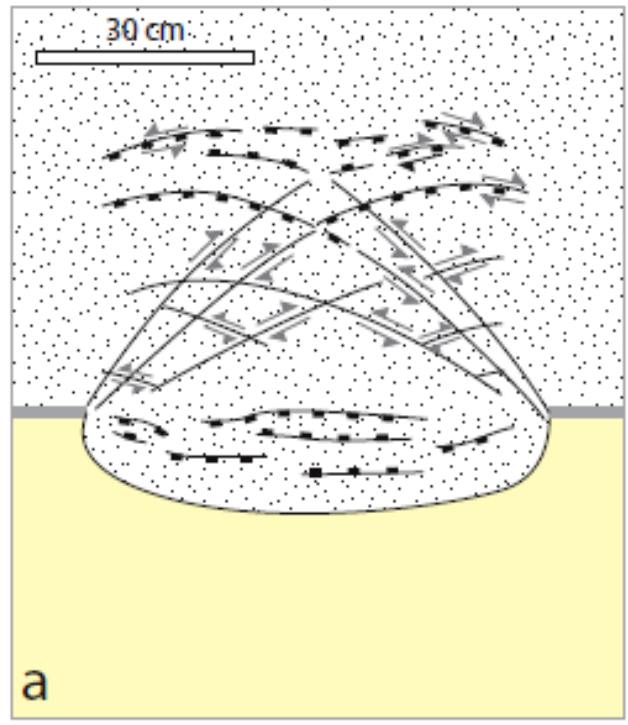

Gravitational collapse $+\mathbf{N}$-S compression

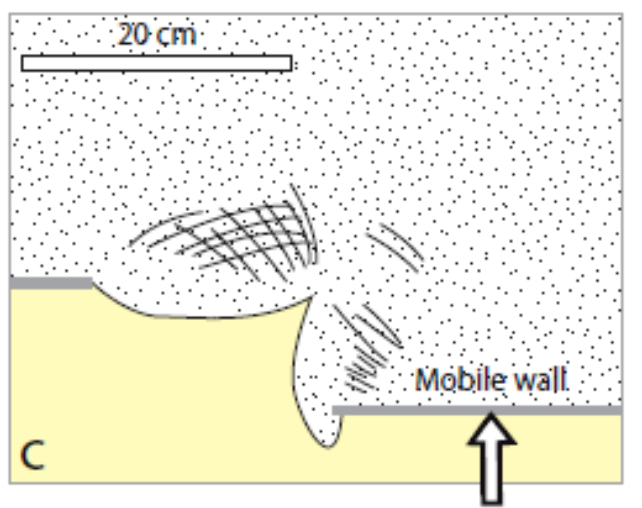

$\begin{array}{ccc}\ldots & \text { normal fault } & \text { strike slip fault } \\ \because & \square \text { model surface }\end{array}$
Hatzfeld et al., 1997

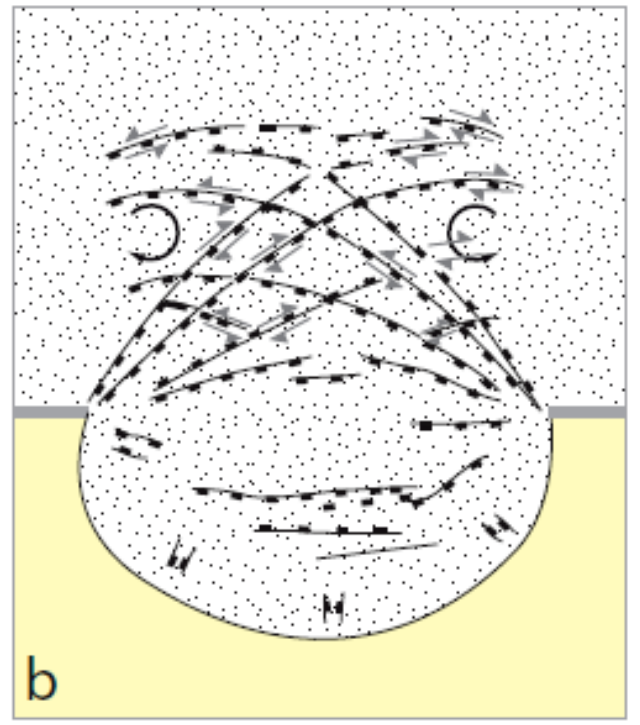

Martinod et al., 2000

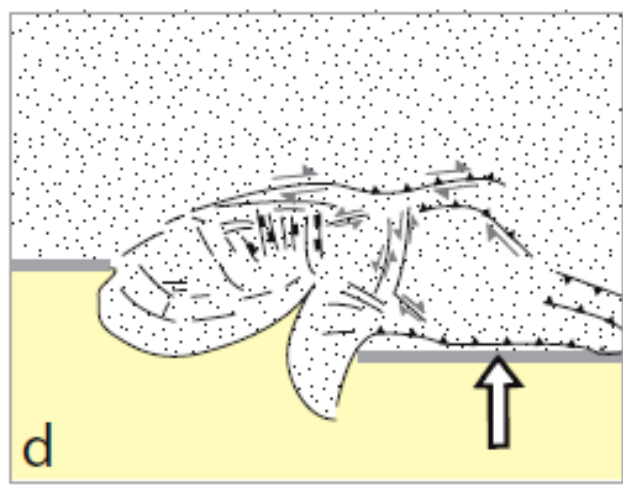

thrust fault $\bigcirc$ block rotation

Figure 4 

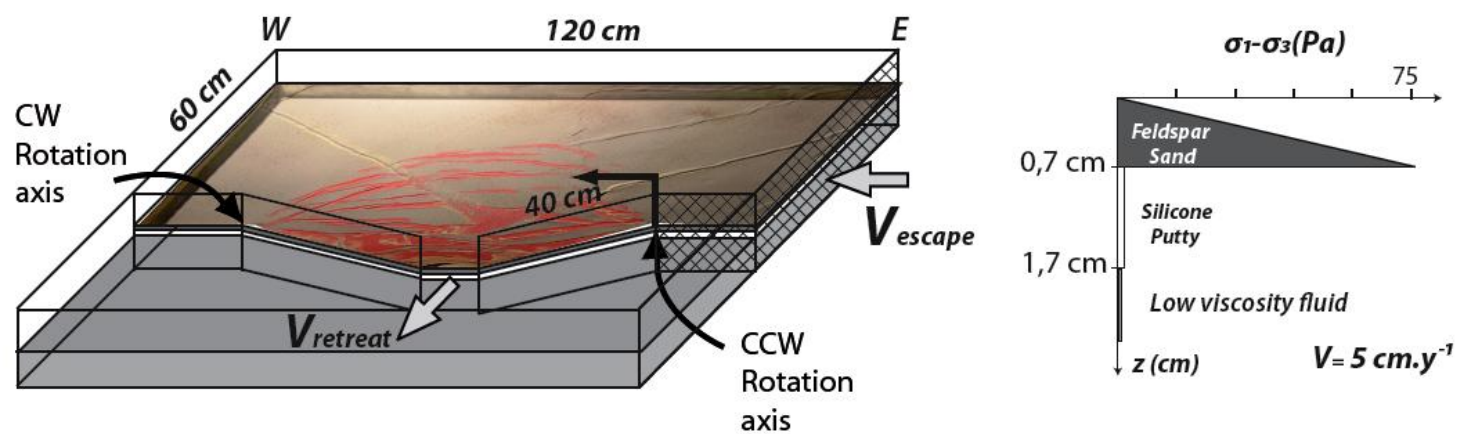

Figure 5 

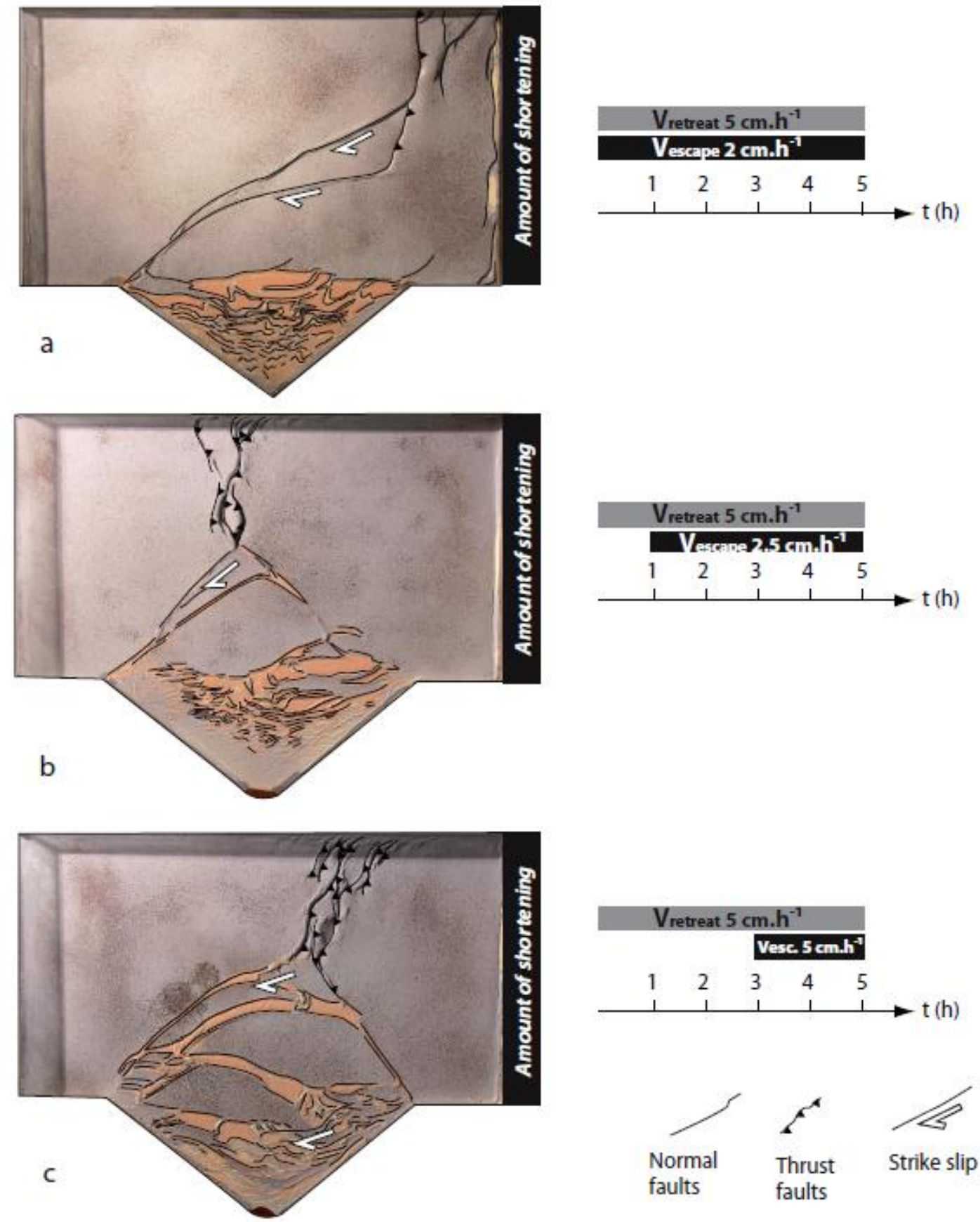

Figure 6 

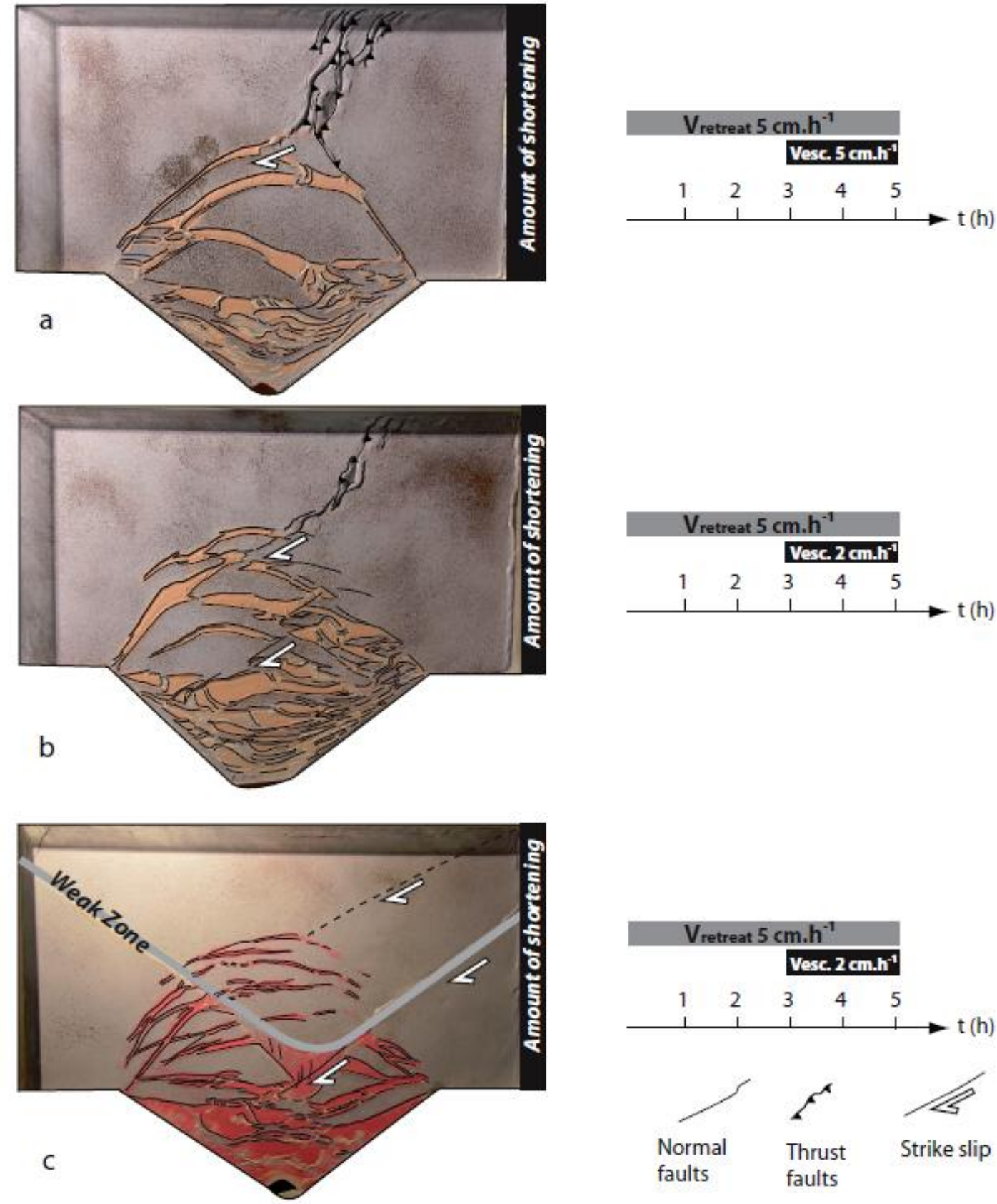

Figure 7 


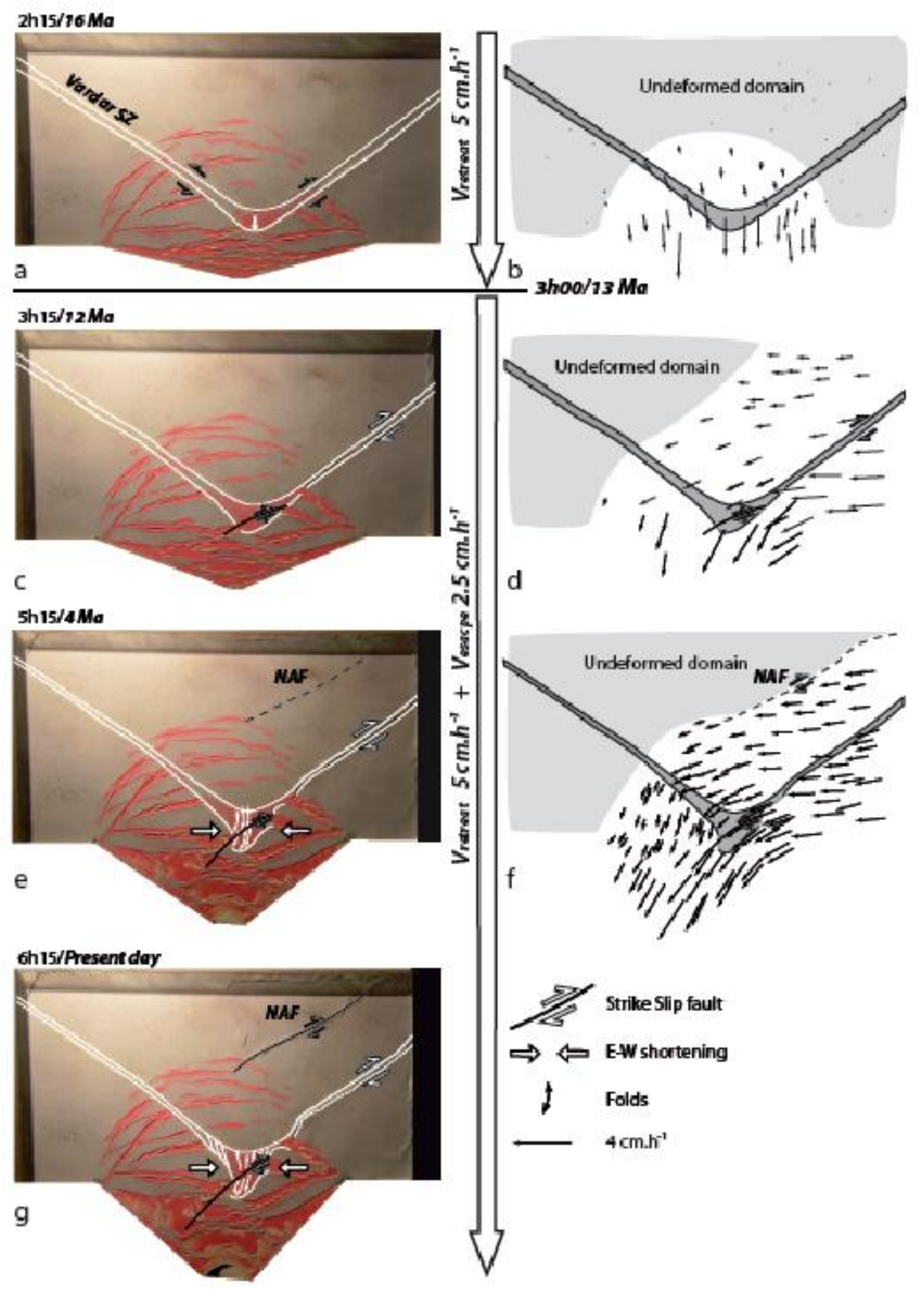

Figure 8 

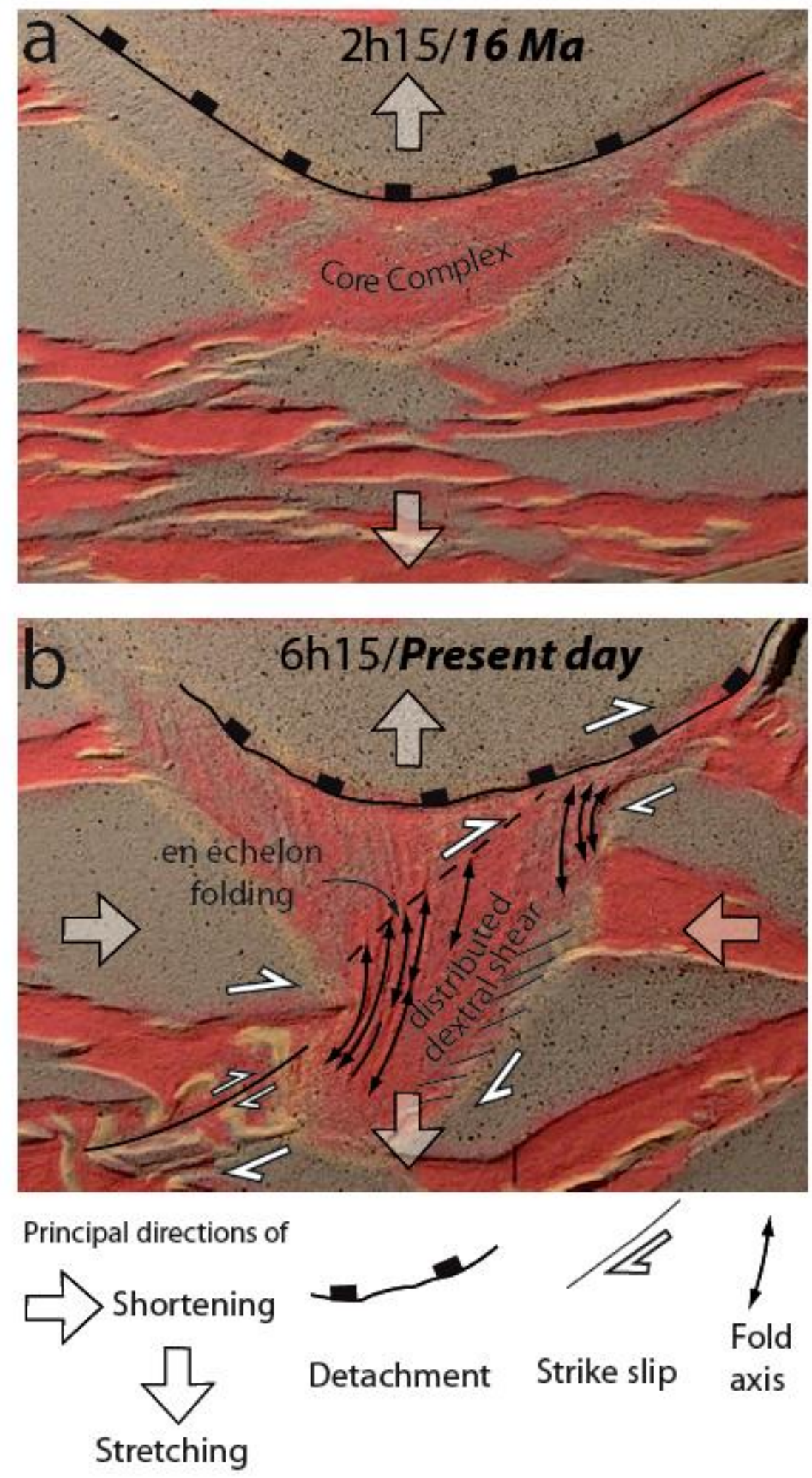

Figure 9 


\section{Nature}

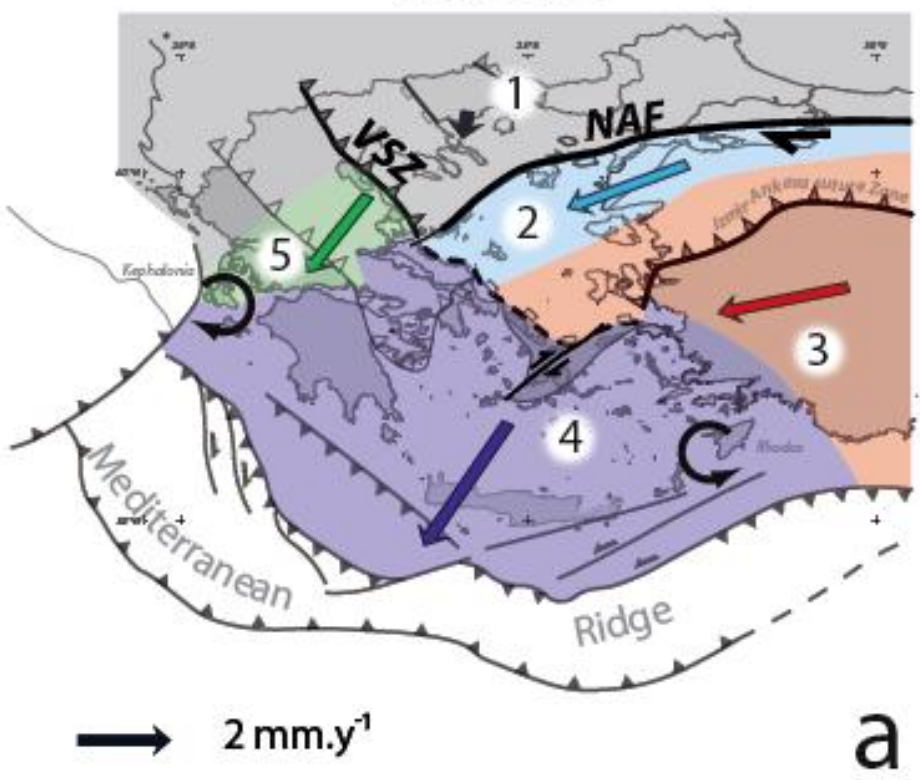

Model

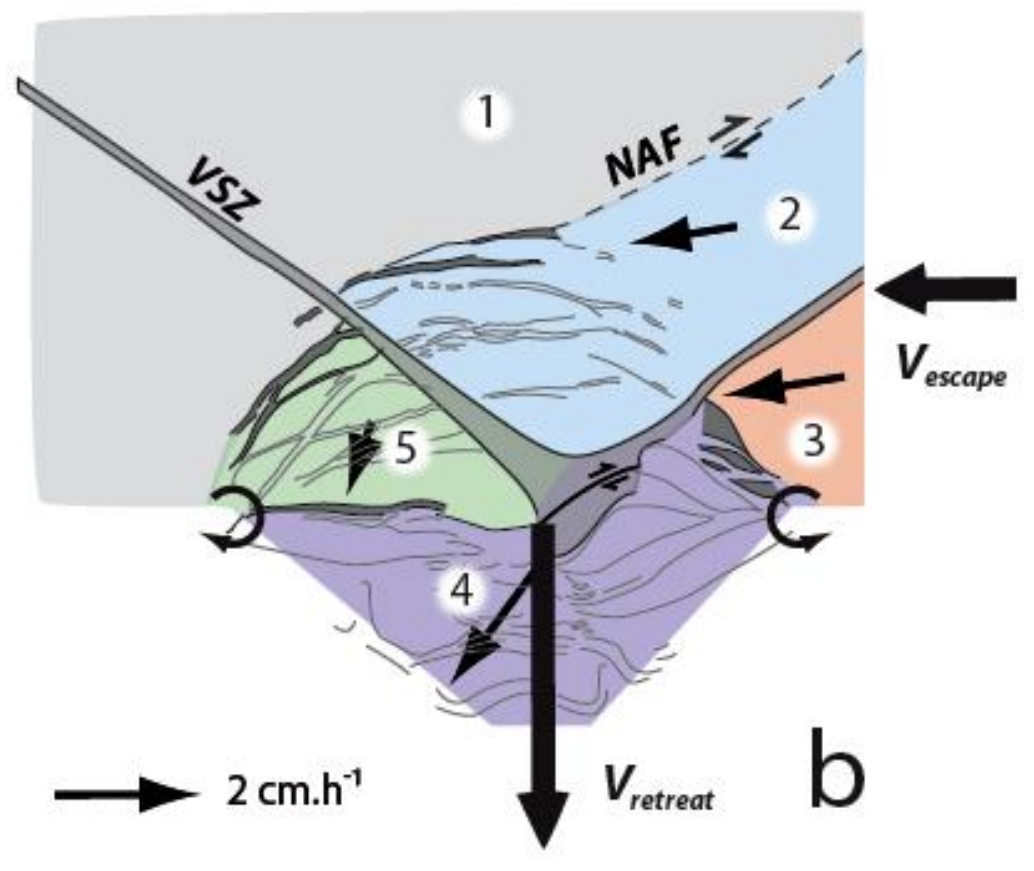

Figure 10 
Table 1

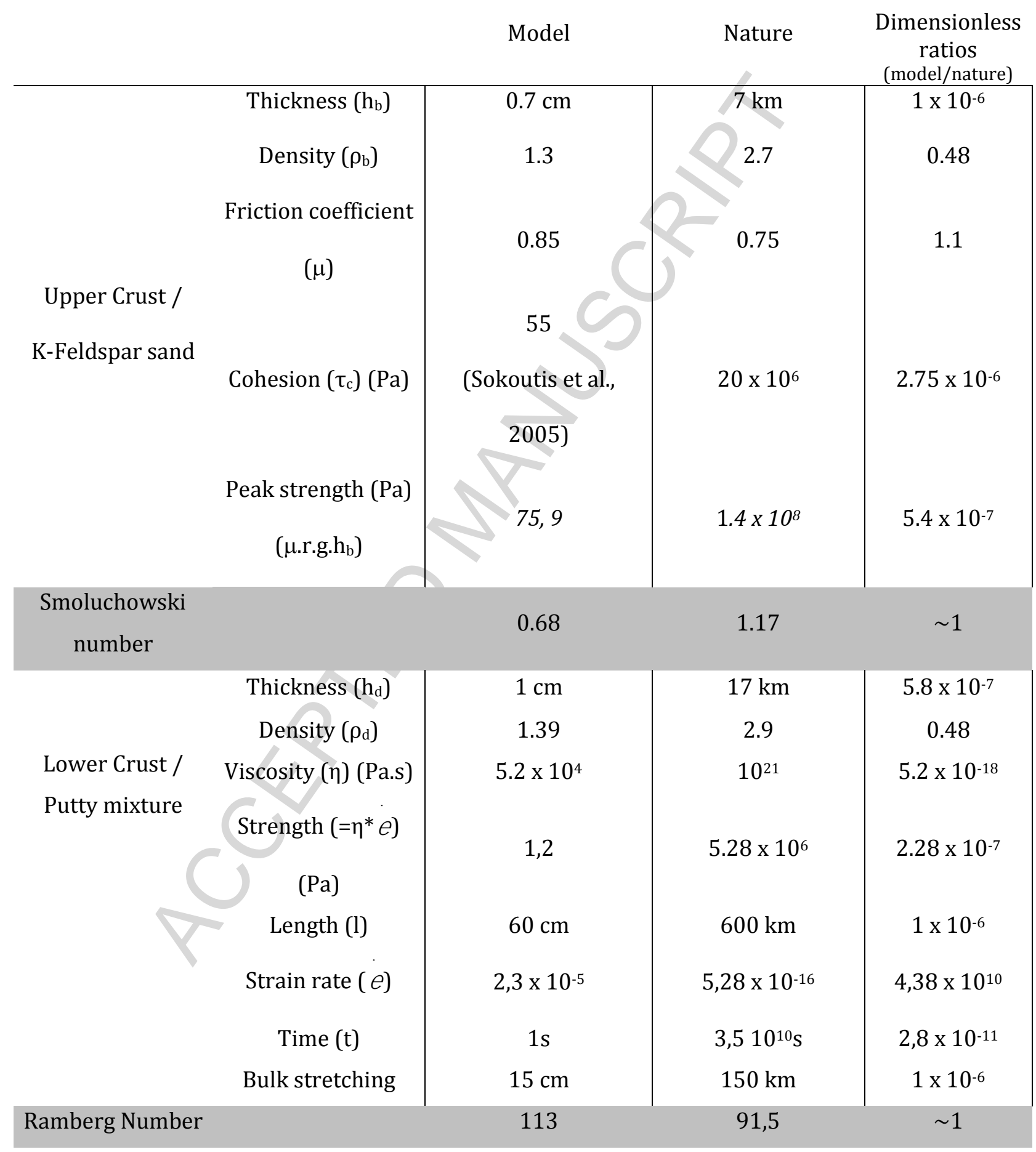


Highlights

- The two stages tectonic evolution of the Aegean is investigated with analogue models.

- Relative timing and rates of trench retreat and Anatolia escape have been tested.

- Models show that inherited structures accommodated the early stages of deformation.

- Models confirm that North Anatolian fault is a late structure (5 Ma).

- Finally, models reproduce the microplates observed in the Aegean with GPS. 